\title{
Covid 19 Pnömonisi Olan Bir Hastada Akut Pankreatit
}

\author{
(iD) Sevil Alkan¹, (ID) Mustafa Yılmaz², (DD Cemile Uyar², (D) Ali Cihat Yıldırım³, (iD) Emine Kübra Dindar Demiray ${ }^{4}$ \\ ${ }^{1}$ Dr. Öğr. Üyesi,Çanakkale Onsekiz Mart Üniversitesi, Tıp Fakültesi, Enfeksiyon Hastalıkları ve Klinik Mikrobiyoloji Anabilim Dalı, \\ Çanakkale, Türkiye \\ ${ }^{2}$ Uzm. Dr., Kütahya Sağlık Bilimleri Üniversitesi, Evliya Çelebi Eğitim Araştırma Hastanesi, Enfeksiyon Hastalıkları ve Klinik \\ Mikrobiyoloji Bölümü, Kütahya, Türkiye \\ ${ }^{3}$ Dr. Öğr. Üyesi, Kütahya Sağlık Bilimleri Üniversitesi,Genel Cerrahi Anabilim Dalı, Kütahya, Türkiye \\ ${ }^{4}$ Uzm. Dr., Bitlis Devlet Hastanesi, Enfeksiyon Hastalıkları ve Klinik Mikrobiyoloji Bölümü, Bitlis, Türkiye
}

$\ddot{0} z$

\section{Covid 19 Pnömonisi Olan Bir Hastada Akut Pankreatit}

Akut pankreatit (AP); bazen ilaç veya toksin yan etkisine, safra kesesi tașlarının pasajı veya sıkıșmasına, viral enfeksiyonlara, alkol kullanımına, bazı metabolik bozukluklara, otoimmün hastalıklara bağlı olarak gelişebilir. ìlk vakanın tespit edildiği Aralık 2019 tarihinden itibaren Korona virüs hastalığı 2019 (COVID-19) enfekte vaka sayılarının artması ile hastalığın sadece akciğer enfeksiyonu olarak değil, farklı klinik tabloları da bildirilmeye devam etmiştir. Sık karşılașılan COVID-19 semptomları solunumsal semptomlar olsa da bazen solunum dıșı semptomlar da gelișebilir. Bulantı, kusma, karın ağrısı ve diyare gibi gastrointestinal (Gı) sistem semptomları ile gelen hastalar olabilir. Çok nadir de olsa pankreatit ile gelen hastalar olabilir. Bu vaka sunumunda; 66 yaşında, başvuru şikayeti karın ağrısı olan, COVID-19 ilișkili olası AP tanısı alan bir olguyu sunmayı amaçladık.

Anahtar Kelimeler: COVID-19, Akut Pankreatit, SARS-CoV-2

\section{Abstract}

\section{Possible Acute Pancreatitis In A Patient With Covid 19 Pneumonia}

Acute pancreatitis (AP) can sometimes develop due to drug or toxin side effects, passage or compression of gallstones, viral infections, alcohol use, some metabolic disorders, and autoimmune diseases. Since the first case was detected in December 2019, with the increase in the number of infected cases of Corona virus disease 2019 (COVID-19), not only lung infection but also different clinical manifestations of the disease continued to be reported. Although respiratory symptoms are common symptoms of COVID-19, non-respiratory symptoms can sometimes develop. There may be patients presenting with gastrointestinal (GI) system symptoms such as nausea, vomiting, abdominal pain and diarrhea. Although very rare, there may be patients presenting with pancreatitis. In this case report, we aimed to present a 66-year-old patient who had abdominal pain at presentation and was diagnosed with possible AP associated with COVID-19. Keywords: COVID-19, Acute Pancreatitis, SARS-CoV-2

\section{Gíriș}

Akut pankreatit, tanım olarak pankreasın inflamasyonu olup, tanısı revize Atlanta kriterlerine göre yapılmaktadır (1). AP etiyolojisinde birçok neden bildirilmiștir. Birtakım ilaçlar, toksinler, viral enfeksiyonlar, alkol, metabolik bozukluklar, otoimmün hastalıklara bağlı veya safra tașlarının pasajı sırasında sıkıșmasına sekonder olarak gelișebilir (1-3).

Akut pankreatit tanısı; aşağıdaki 3 kriterden en az 2'sinin bulunması ile konmaktadır.

1. Akut pankreatit ile uyumlu karın ağrısının olması,

Nasıl Atıf Yapmalı / How to Cite: Alkan S, Yılmaz M, Uyar C, Yıldırım AC, Dindar Demiray EK. Covid 19 Pnömonisi Olan Bir Hastada Akut Pankreatit. MKÜ Tıp Dergisi. 2021;12(43):136-139. https://doi.org/10.17944/mkutfd.887354

Sorumlu Yazar/Corresponding Author: Dr. Öğr. Üyesi, Sevil Alkan

Email: s-ewil@hotmail.com

Geliș/Received: 27 Subat 2021

ORCID iD: 0000-0003-1944-2477 
2. Serum amilaz ve/veya lipaz değerlerinin, normal değerin üst sınırına göre 3 katından daha yüksek bulunması,

3. Radyolojik görüntülemelerde (ultrasonografi, manyetik rezonans görüntüleme veya bilgisayarlı tomografi) pankreatiti destekleyen bulguların saptanması (1-3).

Ilk vakanın tespit edildiği Aralık 2019 itibariyle, COVID-19 188 ülkeyi ve iki milyondan fazla kișiyi etkilemiș ve 120.000'den fazla ölüme neden olmuștur (4). Global olarak artan vaka sayıları ile hastalığın farklı klinik özellikleri de ortaya çıkmıștır. Sık karşılaşılan COVID-19 semptomları, solunumsal semptomlar olsa da bazen solunum dıșı semptomlar da gelișebileceği bildirilmiștir. Bulantı, kusma, karın ağrısı ve ishal gibi GI sistem semptomları ve çok nadir de olsa pankreatit ile gelen hastalar olabilir $(3,5)$.

Bu vaka sunumunda; 66 yașında, başvuru şikayeti karın ağrısı olan COVID-19 ilișkili olası AP tanısı alan bir olguyu sunmayı amaçladık.

\section{OLGU}

66 yașında bilinen hipertansiyon dıșında kronik hastalığı olmayan hasta, 3 gündür olan halsizlik, ishal, kas ağrısı ve aralıklı karın ağrısı șikâyeti ile dış merkezde sağlık kuruluşuna başvurmuş. Hastada akut gastroenterit düşünülerek semptomatik tedavi verilerek kontrol önerilmiş. Herhangi bir ilaç, madde kullanımı olmayan hastanın 15 gün önce il dışı seyahat öyküsü olup, ailesinde de COVID-19 RT-PCR (Polimeraz Zincir Reaksiyonu) pozitifliği olması üzerine hastadan filyasyon ekipleri tarafından COVID-19 RT-PCR testi için nazofarengeal sürüntü örneği alınmıș. Alınan COVID-19 RT-PCR testinin pozitif çıkması üzerine hasta acil servise yönlendirilmiş. Hastadan torakal bilgisayarlı tomografi (BT) istenmiş, çekilen BT'de bulgu saptanmamış. Tarafımıza konsülte edilen hastanın Gi semptomlarının olması ve yapılan tetkiklerinde amilaz/lipaz yüksekliğinin olması üzerine ileri tetkik ve tedavi amaçlı yatırıldı.

Hastanın genel durumu iyi, vital bulguları stabil idi. Fizik muayenesinde barsak seslerinde artma ve batın üst kadranlarda hassasiyet dışında özellik saptanmadı. Hastanın laboratuvar incelemesinde; Aspartat Aminotransferaz: 85U/L, Alanin Aminotransferaz: 193U/L, amilaz: 429 U/L, lipaz: 390 U/L olup diğer parametreler normaldi. Ayırıcı tanı amaçlı istenen, Brusella tetkikleri (Rose Bengal ve Wright), Anti HAV IgM, HBs Ag, Anti Hbs, Anti HBc IgM ve Anti HCV tetkikleri negatif olarak saptandı. Hastadan gaita mikroskopisi ve kültürü de akut gastroenterit ayırıcı tanısı için alındı. Batın ultrasonografik incelemesi normal olarak yorumlandı. Bunun üzerine amilaz/lipaz değerleri de yüksek olan hastadan AP ön tanısı ile bilgisayarlı Batın Tomografisi (BBT) istendi. Çekilen BBT'si normal olarak saptandı (Resim 1). Hastaya sıvı elektrolit desteği ve semptomatik tedaviye ilaveten, PCR pozitifliğinin de olması nedeniyle favipravir tablet ve profilaktik antikoagülan olarak enoksiparin 4000 Anti-XA IU/0.4 ml 10 1x1 subkutan tedavisi de Türkiye Cumhuriyeti Sağlık Bakanlığı COVID-19 Tanı ve Tedavi Rehberi'ne göre bașlandı. Hastanın gaita mikroskopisi normaldi ve kültüründe üreme olmadı. Hastanın takiplerinde karın ağrısı, ishali ve bașlangıçta yüksek olan biyokimyasal tetkikleri geriledi, PCR testi negatiflești. 5 günlük favipravir tedavisi sonrası hasta poliklinik kontrolü önerilerek taburcu edildi.

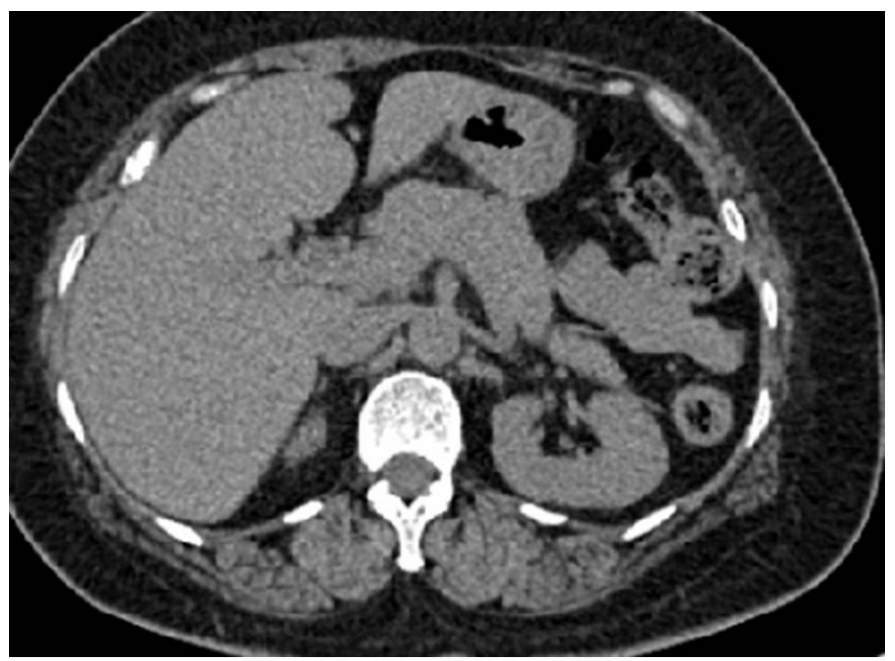

Resim 1. Normal kontrastsız batın BT.

\section{TARTIȘMA}

COVID-19 ilişkili akut pankreatit gelişimi hakkında çok az literatür bilgisi bulunmaktadır. COVID-19 hastalarının bazılarında pankreas enzim yüksekliği ve nadir de olsa AP gelişebilmektedir. AP özellikle ciddi hastalık tablosu ile ilişkilidir (5-9). Önceki yıllarda yapılan çalıșmalarda; viral pankreatitin, Kabakulak, Kızamık, Coxsackie virus, Epstein-Barr virus ve Hepatit-A virüs enfeksiyonuna bağlı gelișebileceği bildirilmiștir. Ancak; COVID-19'un AP'e neden olma potansiyeli olsa da bugüne kadar insanlarda belgelenmemiştir (6). SARS COV 2 dışı koronavirüslerin, gelincik ve güvercinlerde AP yaptığına dair literatür bilgisi mevcuttur $(10,11)$.

Elli iki COVID-19 enfeksiyonu olan vakadan oluşan bir çalıșmada, AP olmadan sadece amilaz/lipaz yüksekliğinin vakaların \%17'sinde saptandığını bildirilmiștir. Bir bașka çalıșmada, AP semptomları olmayan COVID-19 hastalarında izole serum lipaz seviyesinin yükseldiğini bildirilmiștir (13).

Mevcut literatür bilgisi olarak; SARS-CoV-2'nin anjiyotensin dönüștürücü enzim 2’ye (ACE2) ve transmembran proteaz, serin 2 reseptörlerine bağlanarak akciğerler ve Gi sistemdeki hücrelere girdiğini gösteren bazı kanıtlar vardır. İmmün boyamada ACE2'nin pankreasta yüksek oranda eksprese edildiği gösterilmiștir. Bu nedenle, COVID-19 hastalarında AP'nin, virüs replikasyonunun doğrudan sitopatik etkisine bağ|ı geliștiği savunulmaktadır $(12,14,15)$. Ayrıca bir diğer görüş; 
ACE2 reseptörlerinin endotelyal konumu ve SARS-CoV-2 enfeksiyonuna immun yanıtın, COVID-19 hastalarında pankreas damarlarında vasküler tromboza neden olup AP'ye yol açabileceği yönündedir (16). Hatta çocuk bir hastada COVID-19 ilișkili AP bildirilmiștir (14).

Ülkemizden yapılan bir prospektif çalışmada (17); AP'in tek bașına mortaliteye yol açabilen klinik bir durum olduğu ve COVID-19'un progresyonunda gelișen abartılı immün yanıtın nedenlerinden biri olabileceği bildirilmiștir. Çalıșmaya alınan 316 hastanın \%12.6'sında AP saptanmıștır. Hafif hastalarda AP olmayıp, ağır durumdaki hastaların \%7,9'unda $(n=15)$ ve kritik durumdaki hastaların $\% 32,5$ inde $(n=25)$ AP saptanmıștır. C-Reaktif Protein ve ferritin değerleri pankreatiti olanlarda anlamlı olarak daha yüksek olarak saptanmıștır $(p<0.0001)$. Bu çalıșma sonuçları, SARS-CoV-2'nin tetiklediği pankreas hasarı varlığının hastaların klinik durumunu bozabileceğine ve bu hastalarda ölüm oranının artabileceğine işaret ettiği yönündedir. (17).

Ding ve ark. (18) 2003 yılında pankreasın SARS-CoV pnömonisinde potansiyel bir hedef olduğunu bildirmiștir. ACE 2 'nin pankreasta özellikle adacık hücrelerinde eksprese edildiğini ve anjiyotensin-2'nin hiperglisemiye yol açtığını ve ACE-II reseptörleri aracılığıyla diyabetes mellitus gelișimine yol açtığını bildirmiștir. SARS-CoV-2'nin de ACE-II'ye bağlanarak etki gösterdiği bilinmektedir. SARS-CoV-2'ye bağlı pankreas hasarı birkaç vaka serisinde bildirilmiştir, ancak bu durumun hastaIığın seyrine etkisi, tedavi ve takip sırasında oluşturabileceği farklılıklara ilișkin veri kıtlığı bulunmaktadır $(17,19)$.

İtalya'da yapılan bir çalışmada ise (20); 282 COVID-19 hastasının 254ründe pankreas enzimlerinin (PE) yükseldiği bildirilmiștir. Bunların 66ısında (\%26) hafif PE yükselmesi ve 11)inde (\%4.3) şiddetli yükselme (normalin üst sınırının $>3$ katı) saptanmıştır. Sadece, iki hasta AP için tanı kriterlerini karşılamış olup, hepatik ve renal tutulumları olan hastalarda PE yükselmesi saptanmıştı. Çok değişkenli analiz, hafif ve şiddetli pankreatik enzim yükselmelerinin yoğun bakım ünitesine kabul ile anlamlı șekilde ilișkili olduğu bildirilmiștir (20).

Akut pankreatit tek başına mortaliteye yol açabilen klinik bir durumdur ve COVID-19'un progresyonunda gelișen abartılı immün yanıtın nedenlerinden biri olabilir. SARS-CoV2'nin tetiklediği pankreas hasarı varlığının, hastaların klinik durumunu bozabileceğine ve bu hastalarda ölüm oranının artabileceğine ișaret etmektedir. Bildirilmiș COVID-19 ilișkili AP vakalarında da abdominal BT normal sınırlardadır (12-15). Sunduğumuz olguda da amilaz/lipaz yüksekliği mevcut olup, klinik bulgularla da desteklendiğinde COVID-19 PCR pozitifliği olan hasta, COVID-19 ilișkili olası AP olarak değerlendirilmiştir. Önceki veriler AP'nin ciddi klinik bulguları olan COVID-19 hastalarında görülebileceği yönünde olsa da $(5-9,17)$, sunulan vakada akciğer tutulumu mevcut değildi. Hastanın radyolojik tetkikleri normal olup, bu açıdan AP lehine bulgusu saptanmadı. Ancak Atlanta kriterlerine göre hafif AP'de radyolojik olarak normal bulguya rastlanabileceği bildirilmiștir. Bazı çaIıșmacılar AP’te başlangıçta radyolojik görüntüleme normal bile olsa, sonrasında tekrarını önermektedir. Biz amilaz/lipaz değerleri normale dönen, semptomu da kalmayan hastadan temas edilen radyasyon dozunu arttırmamak amaçı tekrar BBT tetkikini istemedik. Hastadan ayrıca tromboz ekartasyonu için, portal venöz USG'de istendi. Ancak patoloji tespit edilmedi. Bunun nedeni tedavi rehberine göre bașlanan erken antikoagülan tedavi ile olası trombozun çözülmüș olması da olabilir.

Sonuç olarak, COVID-19'da pankreas tutulum mekanizması net anlașılamamıștır. Çalıșmalar arasında tutarsız sonuçlar mevcuttur. Bu nedenle bu konudaki çalıșmalara öncelik verilmelidir.

\section{BILDIRIMLER}

Değerlendirme

Dış danışmanlarca değerlendirilmiștir.

Çıkar Çatıșması

Yazarlar bu makale ile ilgili herhangi bir çıkar çatışması bildirmemișlerdir.

Finansal Destek

Yazarlar bu makale ile ilgili herhangi bir malî destek kullanımı bildirmemişlerdir.

Etik Beyan

Bu çalışmada tanımlanan olgudan gerekli izin alınarak "Aydınlatılmış onam formu"nun düzenlenmiș, Helsinki Bildirgesi kriterleri göz önünde bulundurulmuștur.

\section{KAYNAKLAR}

1. Banks PA, Bollen TL, Dervenis C, Gooszen HG, Johnson CD, Sarr MG, et al. Classification of acute pancreatitis 2012: revision of the Atlanta classification and definitions by international consensus. Gut. 2013;62(1):102-111. https://doi.org/10.1136/ gutjnl-2012-302779

2. Çelik M, Demir M, Bulgurcu M, Karakuş A, Kavvasoğlu G . Klaritromisine Bağlı Gelișen Akut Pankreatit. Mustafa Kemal univ. tıp derg. 2015; 3(11): 38-42.

3. Avcı E, Ardahanlı İ, Öztaş E, Dişibeyaz S . CovID-19'da gastrointestinal semptomlar ile hastalığın seyri ve prognozu arasında bir ilișki var mı? Tek merkezli pilot çalıșma. Akademik Gastroenteroloji Dergisi. 2020; 19(3): 103-108.

4. https://www.worldometers.info/coronavirus/ [internet]. [Erişim tarihi: 22.02.2021].

5. Mazrouei SSA, Saeed GA, AI Helali AA. COVID-19-associated acute pancreatitis: a rare cause of acute abdomen. Radiol Case Rep. 2020;15(9):1601-1603. https://doi.org/10.1016/j. radcr.2020.06.019. 
6. Aloysius MM, Thatti A, Gupta A, Sharma N, Bansal P, Goyal H. COVID-19 presenting as acute pancreatitis. Pancreatology. 2020;20(5):1026-1027.

7. Gupta R, Patnaik I, Kumar A. Letter to the editor in response to COVID-19 presenting as acute pancreatitis. Pancreatology. 2020;20(5):1021-1022.

8. Cheung S, Delgado Fuentes A, Fetterman AD. Recurrent Acute Pancreatitis in a Patient with COVID-19 Infection. Am J Case Rep. 2020;21:e927076.

9. Kurihara Y, Maruhashi T, Wada T, Osada M, Oi M, Yamaoka $\mathrm{K}$, et al. Pancreatitis in a Patient with Severe Coronavirus Disease Pneumonia Treated with Veno-venous Extracorporeal Membrane Oxygenation. Intern Med. 2020;59(22):2903-2906.

10. Wills SE, Beaufrere HH, Brisson BA. Pancreatitis and systemic coronavirus infection in a ferret (Mustela putorius furo). Comp Med. 2018;68(3):208-211.

11. Qian DH, Zhu GJ, Wu LZ, Hua GX. Isolation and characterization of a coronavirus from pigeons with pancreatitis. Am J Vet Res. 2006;67(9):1575-1579. https://doi.org/10.2460/ajvr.67.9.1575

12. Wang F, Wang H, Fan J, Zhang Y, Wang H, Zhao Q. Pancreatic Injury Patterns in Patients With Coronavirus Disease 19 Pneumonia. Gastroenterology. 2020 ;159(1):367-370. https:// doi.org/10.1053/j.gastro.2020.03.055.

13. McNabb-Baltar J, Jin DX, Grover AS, Redd WD, Zhou JC, Hathorn KE, et al. Lipase Elevation in Patients With COVID-19. Am J Gastroenterol. 2020;115(8):1286-1288. https://doi. org/10.14309/ajg.0000000000000732.

14. Bineshfar N, Mirahmadi A, Karbasian F, Pourbakhtyaran E, Karimi A, Sarafi M. Acute Pancreatitis as a Possible Unusual Manifestation of COVID-19 in Children. Case Rep Pediatr. 2021;2021:6616211.
15. Dindar Demiray E, Yılmaz M, Alıravcı I, Alkan S. COVID-19Akut Pankreatit illişkisinin İncelenmesi. IGUSABDER. 2021; (13): 130-143.

16. Bikdeli B, Madhavan MV, Jimenez D, Chuich T, Dreyfus I, Driggin E, et al; Global COVID-19 Thrombosis Collaborative Group, Endorsed by the ISTH, NATF, ESVM, and the IUA, Supported by the ESC Working Group on Pulmonary Circulation and Right Ventricular Function. COVID-19 and Thrombotic or Thromboembolic Disease: Implications for Prevention, Antithrombotic Therapy, and Follow-Up: JACC State-of-the-Art Review. J Am Coll Cardiol. 2020 ;75(23):2950-2973.

17. Akarsu C, Karabulut M, Aydin H, Sahbaz NA, Dural AC, Yegul D, et al. Association between Acute Pancreatitis and COVID-19: Could Pancreatitis Be the Missing Piece of the Puzzle about Increased Mortality Rates? J Invest Surg.1-7. Online ahead of print. doi: 10.1080/08941939.2020.1833263.

18. Ding $\mathrm{Y}$, He L, Zhang Q, Huang Z, Che X, Hou J, et al. Organ distribution of severe acute respiratory syndrome (SARS) associated coronavirus (SARS-CoV) in SARS patients: implications for pathogenesis and virus transmission pathways. J Pathol. 2004;203(2):622-630.

19. Liu F, Long X, Zhang B, Zhang W, Chen X, Zhang Z. ACE2 expression in pancreas may cause pancreatic damage after SARS-CoV-2 infection. Clin Gastroenterol Hepatol. 2020;18(9):2128-2130. doi:10.1016/j.cgh.2020.04.040.

20. Troncone E, Salvatori S, Sena G, De Cristofaro E, Alfieri N, Marafini I, et al. Low Frequency of Acute Pancreatitis in Hospitalized COVID-19 Patients. Pancreas. 2021;50(3):393398. doi: 10.1097/MPA.0000000000001770. PMID: 33835971. 